International Journal of Environment, Agriculture and Biotechnology
Vol-6, Issue-1; Jan-Feb, 2021

\title{
Assessment of farmers' vulnerability to climate variability and extreme events: Evidence from dry Kitui, Kenya
}

\author{
Ndung'u C.K.*, Kamau Mercy W., Muriu-Ng'ang'a F.W
}

Department of Environmental Science and Land Resources Management, South Eastern Kenya University, Kitui, Kenya

*Corresponding author, Email: cndungu@ seku.ac.ke

Received: 11 Nov 2020; Received in revised form: 07 Jan 2021; Accepted: 21 Jan 2021; Available online: 16 Feb 2021

(C)2021 The Author(s). Published by Infogain Publication. This is an open access article under the CC BY license

(https://creativecommons.org/licenses/by/4.0/).

\begin{abstract}
Climate variability and extreme events are some of the most pressing environmental challenges occurring in the contemporary world. Farming communities in Sub-Saharan Africa, particularly in arid and semi-arid areas are more vulnerable to climate vulnerability and extremesdue to high dependence on rain-fed agriculture. There is little understanding of factors influencing farmers'vulnerability to climate variability and extremes at household level in arid and semi-arid parts of Kenya. This study analyzed farmers'vulnerability to climate variability and extremes in arid and semi-arid parts of Kitui County, Kenya. The study utilized data collected from 341 households from Yuku, Kaveta, Kauwi and Kasaini sub-locations located in four different agro-ecological zones. Descriptive survey was used and purposive sampling method applied in identifying the sub-locations of study. Proportionate sampling was used to select the number of households to be interviewed in each sub-location and systematic sampling used to select the households which formed the units of analysis. Vulnerability analysis was based on indices constructed from carefully selected indicators for exposure, sensitivity, and adaptive capacity. The indicators were weighted using Equal Weight Analysis. Vulnerability indices indicated that Yuku sub-location (arid) was the most vulnerable to climate variability and extreme events (1.487) followed by transitional zone from semi-arid to semi-humid-Kauwi (0.214), semi-arid-Kasaini (0.085) and semi-humid-Kaveta sub-location (-0.530). Development and policy measures should be focused towards improving the adaptive capacity of the rural farming households, while keeping the post-disaster emergency relief measures in place for zones with higher biophysical vulnerability to climate variability and extremes.
\end{abstract}

Keywords-Exposure, sensitivity, adaptive capacity, and agro-ecological zones.

\section{INTRODUCTION}

Natural climate variability and extremes have been identified as major challenges facing human livelihoods globally. Anthropogenic climate change has added a complex new dimension to this challenge. Studies have shown that natural climatic variability, compounded with human induced climate change will adversely affect millions of livelihoods around the world (LVBC, 2011). Worldwide, the livelihoods of 2.5 billion people depend on rain-fed agriculture (FAO, 2016). These small-scale farmers, herders, beekeepers, fishers and forest-dependent communities generate more than half of the global agricultural production and are particularly at risk from climate variability and extremes that destroy harvests, equipment, supplies, livestock, seeds, crops and stored food.

In Africa, climate is warmer than it was 100 years ago and model-based predictions of future human-induced climate change for the continent clearly suggest that this warming will continue and, in most scenarios, accelerate (Christensen et al., 2007). Observational records by Hulme et al. (2001) 
showed that during the $20^{\text {th }}$ century, Africa warmed at a rate of about $0.05^{\circ} \mathrm{C}$ per decade. Rural households in Sub Sahara Africa (SSA), predominantly those in arid and semi-arid regions are likely to be more exposed and vulnerable to impacts of climate variability and extremes, a situation aggravated by limited knowledge regarding the implementation and effectiveness of current measures taken up to reduce exposure and vulnerability (Spear et al., 2015).

In Kenya, the impact of climate change has been more pronounced in the Arid and Semi-Arid Lands (ASALs) which supports $25 \%$ of the country's total human population that relies on nearly $75 \%$ livestock and crop production. The agricultural sector is a key contributor to Kenya's economic growth. The sector is estimated to contribute at least $25 \%$ of the country's GDP (Republic of Kenya, 2005). The productivity of this sector has conversely been compromised by the effects of climate change and variability. In recent years, Eastern Africa (Kenya included), has been known to be prone to climate variability. Anomalous strong rainfall events seem to have increased (Van Oldenborgh et al., 2008). The temperatures in these regions have also been increasing considerably due to the changing climate. The situation is exacerbated by increasing climate induced extreme events such as floods, droughts, pests, diseases among others which have resulted in a reduction in the economic activities practiced in such regions (Zoellick, 2009).

Kitui County is one of the ASALs counties in Kenya. A large part of the county receives erratic and unreliable rainfall with most of the areas being generally hot and dry leading to high rate of evaporation (Khisa et al., 2014). The county has been experiencing a reduction in food production because of its vulnerability to changing and erratic rainfall pattern which has adversely affected the agricultural sector. Variations in climatic conditions experienced in the county are thought to be responsible for crop failure and changes in food production. Agriculture dependent households particularly, have been and continue to be vulnerable to climate variability and extremes (Khisa et al., 2014).

Contemporary research efforts on vulnerability to climate variability and extremes have focused on regional and national assessments of the potential impacts and adaptive capacity of farmers. The current study focused on household level analysis of farmers' vulnerability to climate variability and extremes in different agro-ecological zones.

\section{MATERIALS AND METHODS}

\subsection{The study area}

The study area consisted of Yuku, Kaveta, Kauwi and Kasaini sub-locations in Kitui County which represented arid, semi-humid, transition from semi-arid to semi-humid and semi-arid zones respectively (Figure 1). Kitui County is located between longitudes $37^{\circ} 45^{\prime}$ and $39^{\circ} 0^{\prime}$ East and Latitudes $0^{\circ} 3.7^{\prime}$ and $3^{\circ} 0^{\prime}$ South (GoK, 2009b). The county lies between $400 \mathrm{~m}$ to $1,830 \mathrm{~m}$ above sea level and generally slopes from west to east. The climate of the area is semi-arid with very erratic and unreliable rainfall.The temperatures range from a minimum of $14-22^{\circ}$ centigrade to a maximum of $26-34^{\circ}$ centigrade. Rainfall is bimodal distributed within two seasons yearly and varies from $500-1050 \mathrm{~mm}$ with about $40 \%$ reliability.The soil types range from sedimentary rocks, red sandy soils, to clay black cotton soils which are generally low in fertility. 


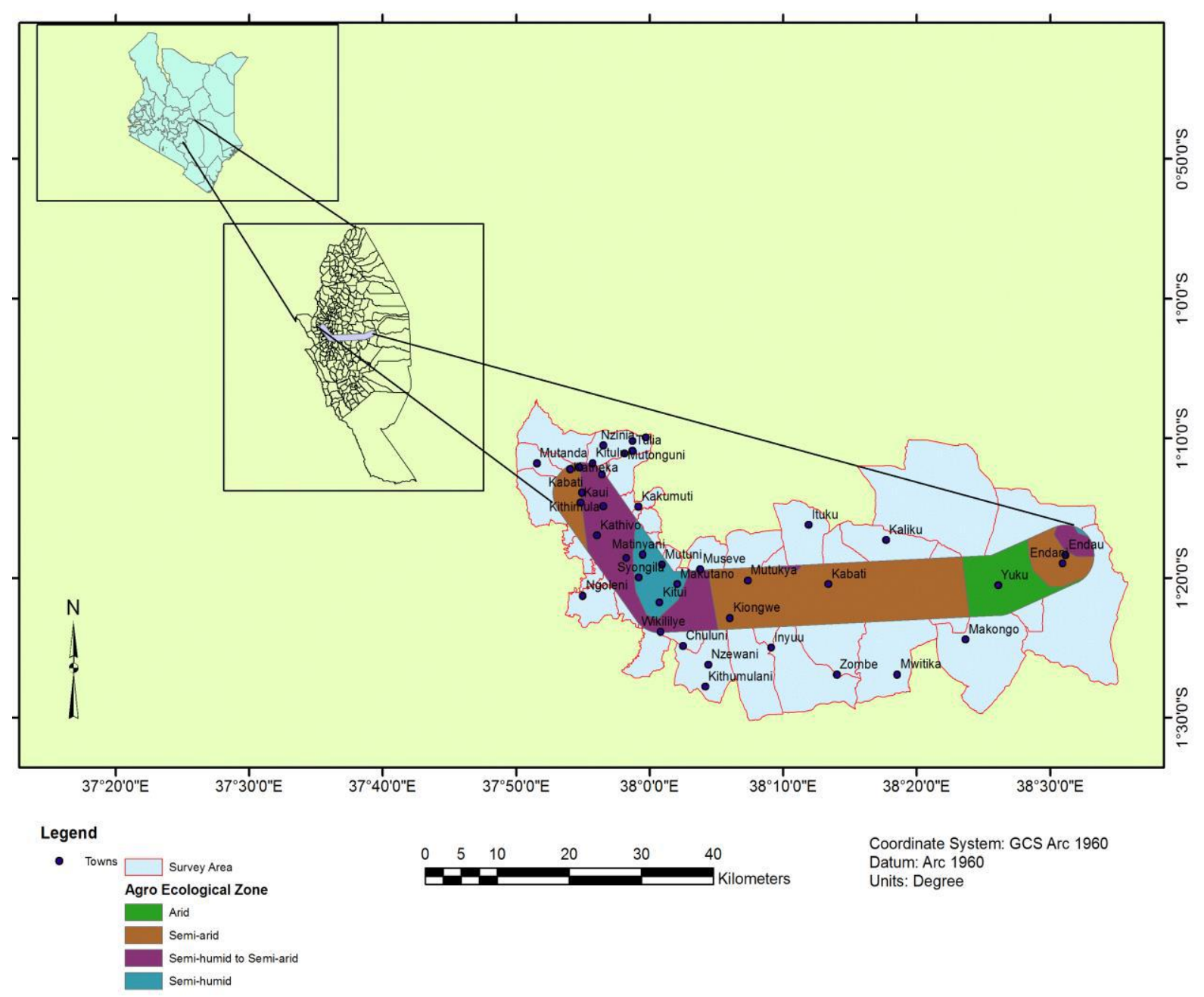

Fig.1: Map of the Study Area

(Source: ILRI GIS database)

\subsection{Research design, data collection and data analysis}

This study used descriptive survey design. Purposive sampling was used to select the sub-locations while simple random sampling was used to select the households. Households were selected as the main units of analysis because major decisions about adaptation to climate induced stresses and livelihood processes are taken at that level. For this study, four sub-locations were selected namely; Yuku, Kaveta, Kauwi and Kasaini which represented arid, semihumid, transition from semi-arid to semi-humid and semiarid zones of Kitui County, respectively. The aim of selecting the four sub-locations was to gain insights into differences in farmers' vulnerability to climate variability and extremes as influenced by the different agro-ecological zones. The sample size for the study was 341 households
$($ Yuku= 39, Kaveta $=104$, Kauwi $=160$ and Kasaini $=38)$. Primary data was collected through household interviews and personal observation while secondary data was obtained from desktop studies. Statistical Package for Social Sciences (SPSS version 20) was used to analyze the quantitative data.

\subsection{Choosing vulnerability indicators}

The steps in constructing the vulnerability index comprised of the selection of indicators for exposure, sensitivity and adaptive capacity, assignment of weights to the indicators and finally aggregating them to form vulnerability index. The selection of suitable indicators for exposure, sensitivity and adaptive capacity was done based on theories that provided insight into the nature and causes of vulnerability complemented by personal observations.

\subsubsection{Exposure}


The number of extreme climate related natural disasters were taken as indicators of exposure. These included floods, droughts, storms/strong winds, livestock diseases, wild forest fires, community inter-border conflicts and human wildlife conflicts and the data was collected through household survey. It was hypothesized that the higher the number of climate related disasters, the higher the exposure of the agroecological zone to climate variability and extremesthus an increasing functional relationship $(\uparrow)$.

\subsubsection{Sensitivity}

Sensitivity was indicated by the degree to which climaterelated stimuli adversely affected land, water resources and household income structure. For the purpose of this study, human fatalities, livestock fatalities, share of natural and non-natural based income, water quantity and property damages (land, houses, roads, trees and crop) due to climate related disasters over a period of ten years were the subindicators of sensitivity. This was in line with Luni et al. (2012) who while working on vulnerability of rural households to climate change and extremes in the Mid-Hills of Nepal used deaths of family members, loss of properties (land, livestock, and crop) due to climate related disasters and income structure as determinants of household sensitivity. It was hypothesized that higher livelihood impacts of climate related disasters, higher share of natural resource based income, and increased frequency of water sources drying up increases sensitivity thus an increasing functional relationship with vulnerability $(\uparrow)$. On the converse, higher share of non-natural resource based remunerative income sources will reduce the sensitivity thus a decreasing functional relationship with vulnerability $(\downarrow)$.

\subsubsection{Adaptive capacity}

For this study, indicators for adaptive capacity were based on the DFID sustainable livelihoods framework, where adaptive capacity is taken to be an emergent property of human, social, natural, physical and financial assets possessed by the households (DFID, 1999; Ellis, 2000). Any indicator with a positive relationship with adaptive capacity results to a decreasing functional relationship $(\downarrow)$ with vulnerability while indicators that reduce adaptive capacity ultimately increase vulnerability $(\uparrow)$.

\subsection{Construction of vulnerability index}

Having selected the indicators of different components of vulnerability and their functional relationship with vulnerability identified, the UNDP's Human Development Index (HDI) (UNDP, 2006) was followed to normalize them. This was done in order to obtain comparable figures free from the units and scales of the indicators. Variables with a $\uparrow$ functional relationship with vulnerability were normalized using the formula:

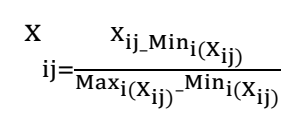

Where; $X_{i j}$ is the value of the indicator $j$ corresponding to region $i$

$\operatorname{Min}_{\mathrm{i}\left(\mathrm{X}_{\mathrm{ij}}\right)}$ is the smallest value of the indicator in all the study areas and $\operatorname{Max}_{\mathrm{i}}\left(\mathrm{X}_{\mathrm{ij})}\right.$ is the largest value of the same indicator.On the other hand, normalized score for variables with a $\downarrow$ functional relationship with vulnerability were computed using the formula:

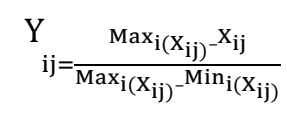

Equal weights were given to all variablesandsimple average of all the normalized scores used to construct the vulnerability index by using the formula:

$\mathrm{VI}=\frac{\sum_{j} X_{i j+\sum_{j} Y_{i j}}}{K}$ where $\mathrm{K}$ is the number of used indicators.Vulnerability index of each agro-ecological zone was calculated as: $\mathrm{V}=\mathrm{E}+\mathrm{S}-\mathrm{AC}$, where, $\mathrm{V}$ is the vulnerability index, $\mathrm{E}$ is exposure index, $\mathrm{S}$ is sensitivity index and $\mathrm{AC}$ is adaptive capacity index (Ndungu et al., 2015).

For the purpose of this study, the above-namedformula was modified and expressed as: $\mathrm{V}=\mathrm{PI}-\mathrm{AC}, \quad$ where, $\mathrm{PI}$ is potential impact index $(\mathrm{E}+\mathrm{S})$ and $\mathrm{AC}$ is adaptive capacity index.

The vulnerability indices were then used to rank the different agro-ecological zones in terms of vulnerability. A zone with highest index was said to be most relatively vulnerable and was assigned the rank 1while the zone with next highest index was given rank 2 and so on. Negative value of the index did not imply that the agro-ecological zone was not vulnerable at all rather; it meant that the study site was comparatively less vulnerable.

\section{RESULTS AND DISCUSSION}

\subsection{Exposure of farmers to climate variability and extremes in the study area}

Close analysis of the results indicated that, number of floods, droughts and livestock diseases over a period of ten years was highest in Yuku (at 1.03, 7.56 and 4.92 respectively) followed by Kauwi (0.72, 6.69 and 3.41), Kasaini (0.37, 4.79 and 2.45) and Kaveta at 0.08, 4.46 and 1.84. There was a 
statistically significant difference in the mean values for the number of floods, wild/ forest fires, community inter-border conflicts and incidences of human-wildlife conflictacross the four sub-locations $(\mathrm{p}<0.05$; Table 1$)$.

It is evident that farmers in Yuku (arid) and Kauwi (transitional zone from semi-arid to semi-humid) experienced higher number of climate related natural disasters compared to those in semi-arid and semi-humid zones. The high number of disasters highlighted the zones' exposure to climate variability and extremes due to property and infrastructural damages. This could be attributed to high number of floods, droughts, strong winds, wild/ forest fires, community inter-border conflicts, incidences of humanwildlife conflicts and livestock diseases. The situation was exacerbated by the fact that thearid and transitional zones had shallow soils with low water retention capacity and thus prone to disasters such as floods and droughts. Conversely, farmers in Kaveta (semi-humid) and Kasaini (semi-arid) experienced comparatively lower incidences of the disasters thus reducing their exposure to extreme events. The soils in semi-humid and semi-arid zones are predominantly loam and cotton in nature and thus less prone to disasters such as floods and droughts. Moreover, farmers in Kaveta and Kasaini had better access to extension services and weather information and thus better adapted against the disasters.

Similar findings by Ndungu et al. (2015) while working in Mid-hills of Himachal Pradesh in India indicated that increase in natural disasters such as droughts, floods among others lead to property destruction and subsequent exposure of farmers to hazards. In addition, findings by Luniet al. (2012) indicated that the number of natural disasters experienced in a locality is a salient component to determine the overall exposure of the locality.

Table 1: Mean values for Indicators of Exposure in the study area

\begin{tabular}{|c|c|c|c|c|c|c|}
\hline Indicators & $\begin{array}{l}\text { Aggregate } \\
(n=341)\end{array}$ & $\begin{array}{l}\text { Yuku } \\
(n=39)\end{array}$ & $\begin{array}{l}\text { Kaveta } \\
(n=104)\end{array}$ & $\begin{array}{l}\text { Kauwi } \\
(n=160)\end{array}$ & $\begin{array}{l}\text { Kasaini } \\
(\mathbf{n}=\mathbf{3 8})\end{array}$ & $\begin{array}{l}\text { P- } \\
\text { Value }\end{array}$ \\
\hline Floods & $0.41(1.16)$ & $1.03(2.07)$ & $0.08(0.34)$ & $0.71(1.16)$ & $0.37(1.65)$ & $0.00^{* *}$ \\
\hline Droughts & $5.90(9.80)$ & $7.56(5.39)$ & $4.46(4.70)$ & $6.69(13.32)$ & $4.79(3.97)$ & 0.18 \\
\hline $\begin{array}{l}\text { Storms/strong } \\
\text { winds }\end{array}$ & $3.82(8.07)$ & $6.49(6.76)$ & $2.87(5.18)$ & $4.11(10.21)$ & $2.50(4.10)$ & $0.02 * *$ \\
\hline Wild/forest fires & $0.15(1.40)$ & $0.92(3.72)$ & $0.11(0.99)$ & $0.03(0.25)$ & $0.00(0.00)$ & $0.00 * *$ \\
\hline Livestock diseases & $3.00(7.74)$ & $4.92(5.82)$ & $1.84(3.42)$ & $3.41(10.35)$ & $2.45(3.78)$ & 0.14 \\
\hline $\begin{array}{l}\text { Community inter- } \\
\text { border conflicts }\end{array}$ & $0.62(2.22)$ & $2.90(4.72)$ & $0.66(2.00)$ & $0.16(0.99)$ & $0.13(0.81)$ & $0.00 * *$ \\
\hline $\begin{array}{l}\text { Human-wildlife } \\
\text { conflicts }\end{array}$ & $0.42(2.04)$ & $3.08(5.10)$ & $0.04(0.24)$ & $0.05(0.22)$ & $0.26(1.62)$ & $0.00 * *$ \\
\hline Total disasters & $14.32(32.41)$ & $26.90(71.90)$ & $10.06(10.24)$ & $14.89(27.59)$ & $10.50(10.10)$ & $0.00 * *$ \\
\hline
\end{tabular}

Note: Figures in parenthesis indicate standard deviation

** indicate significant at $5 \%$ level of significance

\subsubsection{Sensitivity of farmers to climate variability and extreme events in the study area}

Scrutiny of the results indicated that mean values for human fatalities, livestock fatalities, number of houses damaged, roads and productive land damaged as a result of the climate related natural disasters over a period of ten years were statistically significant $(\mathrm{p}<0.05)$ across the four sub-locations (Table 2). The results revealed that livelihood damage caused by climate related natural disasters under study was highest in Yuku and lowest in Kaveta sub-location. This could be explained by proximity of Yuku sub-location to Transnational park and Kitui South conservation area thus increasing human-wildlife conflicts. Moreover, neighboring pastoral communities often experience severe droughts leading to invasion into the area in search for pasture and water. This eventually raises tension between the communities thus increasing the incidences of community inter-border conflicts. Further, higher sensitivity of farmers to climate variability and extremes in Yuku can be explained by high incidences of drought and short but very intensive 
and destructive rainfall events that are common in thearea thereby contributing to more damages in the arid zone.

The share of natural resource-based income was highest in Yuku followed by Kasaini, Kauwi and lowest in Kaveta sublocation. On the contrary, share of non-natural resourcebased income was highest in Kaveta sub-location and lowest in Yuku sub-county. Higher share of natural resource-based income compared to non-natural resource-based income in Yuku and Kasaini could be attributed to the nature of livelihoods in the two zones which were predominantly based on natural-resource based activities notably agriculture, livestock, sand harvesting, handicraft and forestry. The education levels in the two areas were lower compared to Kaveta and Kauwi, thus making it difficult for people from these areas to secure professional jobs out of the usual natural based activities. Moreover, Yuku and Kasaini are quite far from the county headquarters where most non- natural income generating opportunities are found. Conversely, the higher ratio of non-natural resource-based income to natural resource-based income in Kaveta and Kauwi sub-locations could be explained by the nature of livelihoods in the areas. Income generating activities in these areas are primarily non-natural resources based and includeformal employment, non-skilled off farm employment and other trainings. Kaveta and Kauwi are near the County headquarters where formal and non-formal off farm opportunities are available. In addition, education levels in Kaveta and Kauwi were relatively high making it easier for residents to acquire skilled jobs in the County headquarters or even outside the County. Increase in share of non-natural resource-based income had a negative functional relationship with sensitivity while increase in share of natural resource-based income increased farmers' sensitivity as such resources are highly dependent on climate.

Table 2: Mean values for fatalities, damages and income indicators of sensitivity in the study area

\begin{tabular}{|c|c|c|c|c|c|c|}
\hline Indicators & $\begin{array}{l}\text { Aggregate } \\
(n=341)\end{array}$ & $\begin{array}{l}\text { Yuku } \\
(n=39)\end{array}$ & $\begin{array}{l}\text { Kaveta } \\
(\mathrm{n}=104)\end{array}$ & $\begin{array}{l}\text { Kauwi } \\
(n=160)\end{array}$ & $\begin{array}{l}\text { Kasaini } \\
(\mathbf{n}=38)\end{array}$ & $\begin{array}{l}\text { P- } \\
\text { Value }\end{array}$ \\
\hline Human fatalities & $5.28(71.64)$ & $45.18(209.94)$ & $0.19(0.78)$ & $0.09(0.45)$ & $0.05(0.32)$ & $0.00^{* *}$ \\
\hline Livestock fatalities & $27.16(208.42)$ & $204.44(593.00)$ & $2.24(4.76)$ & $5.56(10.23)$ & $4.39(8.08)$ & $0.00^{* *}$ \\
\hline $\begin{array}{l}\text { Number of houses } \\
\text { damaged }\end{array}$ & $0.36(1.39)$ & $1.87(3.50)$ & $0.14(0.53)$ & $0.21(0.59)$ & $0.03(0.16)$ & $0.00 * *$ \\
\hline Roads damaged & $0.12(1.10)$ & $0.85(3.17)$ & $0.03(0.22)$ & $0.00(0.00)$ & $0.00(0.00)$ & $0.00^{* *}$ \\
\hline $\begin{array}{l}\text { Productive land } \\
\text { damaged }\end{array}$ & $0.98(3.71)$ & $4.03(9.82)$ & $0.28(0.76)$ & $0.81(1.71)$ & $0.36(1.07)$ & $0.00^{* *}$ \\
\hline $\begin{array}{l}\text { Share of total natural } \\
\text { resource-based income }\end{array}$ & $\begin{array}{l}47325.20 \\
(98017.40)\end{array}$ & $\begin{array}{l}60909.00(52706.0 \\
0)\end{array}$ & $\begin{array}{l}40054.90 \\
(54726.30)\end{array}$ & $\begin{array}{l}46828.20 \\
(125985.50)\end{array}$ & $\begin{array}{l}54471.10(92 \\
137.90)\end{array}$ & 0.68 \\
\hline $\begin{array}{l}\text { Share of total non- } \\
\text { natural resource-based } \\
\text { income }\end{array}$ & $\begin{array}{l}130169.80 \\
(475022.90)\end{array}$ & $\begin{array}{l}33423.10(58392.8 \\
0)\end{array}$ & $\begin{array}{l}164466.30(6 \\
33050.40)\end{array}$ & $\begin{array}{l}138441.30(3 \\
37962.20)\end{array}$ & $\begin{array}{l}62418.40(10 \\
0181.70)\end{array}$ & 0.36 \\
\hline
\end{tabular}

Note: Figures in parenthesis indicate standard deviation

** indicate significant at $5 \%$ level of significance

Vulnerability of water resources to climate variability was indicated the number of times the water sources had dried up over a period of ten years as indicated in Table 3 . The results indicated that the number of times water sources had dried up over a period of ten years were highest in Yuku sublocation and lowest in Kaveta sub-location. (Table 3). This could be attributed by severe waters scarcity in Yuku forcing farmers to frequent their visits to the water sources in search for household and livestock water. Farmers revealed that the water sources dried up twice every year after every rainy season. On the contrary, farmers in Kaveta had alternative water sources such as piped water and thus, they did not visit the water sources frequently. Moreover, Kaveta being semihumid, the water sources had adequate water and hardly dried up except during rare prolonged droughts.

The study concluded that income structure and impacts of climate related disasters on livelihoods and water quality influenced the overall sensitivity index. The study also 
revealed that high share of non-natural based income assists to decrease the overall household sensitivity, while higher share of natural resource-based income makes the household more sensitive to climate change and extremes.

The current trend of results is in consonance with findings of Collier et al. (2008) and Davis et al. (2007) who reported that off farm income is stable, reliable and less climate sensitive. Similarly Ndunguet al. (2015) established a positive relationship between effects of extreme events on physical properties, livestock and land, and sensitivity of the communities to the changing climate.

Table 3: Mean values for indicators of water quantity in water sources in the study areas

\begin{tabular}{|c|c|c|c|c|c|c|}
\hline Indicators & $\begin{array}{l}\text { Aggregate } \\
(n=341)\end{array}$ & $\begin{array}{l}\text { Yuku } \\
(n=39)\end{array}$ & $\begin{array}{l}\text { Kaveta } \\
(n=104)\end{array}$ & $\begin{array}{l}\text { Kauwi } \\
(n=160)\end{array}$ & $\begin{array}{l}\text { Kasaini } \\
(n=38)\end{array}$ & $\begin{array}{l}\text { P- } \\
\text { Value }\end{array}$ \\
\hline $\begin{array}{l}\text { Number of times the nearest river had dried up } \\
\text { (over a period of } 10 \text { years) }\end{array}$ & $5.23(4.59)$ & $\begin{array}{l}5.44 \\
(4.79)\end{array}$ & $4.31(4.48)$ & $\begin{array}{l}5.76 \\
(4.53)\end{array}$ & $\begin{array}{l}5.32 \\
(4.68)\end{array}$ & $0.04 * *$ \\
\hline $\begin{array}{l}\text { Number of times the nearest borehole had } \\
\text { dried up (over a period of } 10 \text { years) }\end{array}$ & $1.41(3.37)$ & $\begin{array}{l}2.85 \\
(4.72)\end{array}$ & $1.53(3.25)$ & $\begin{array}{l}1.08 \\
(3.04)\end{array}$ & $\begin{array}{l}1.05 \\
(3.11)\end{array}$ & $0.03 * *$ \\
\hline $\begin{array}{l}\text { Number of times nearest shallow well dried } \\
\text { up (over a period of } 10 \text { years) }\end{array}$ & $3.45(4.40)$ & $\begin{array}{l}4.72 \\
(4.85)\end{array}$ & $2.47(3.96)$ & $\begin{array}{l}3.69 \\
(4.46)\end{array}$ & $\begin{array}{l}3.82 \\
(4.49)\end{array}$ & $0.03 * *$ \\
\hline $\begin{array}{l}\text { Number of times nearest spring dried up (over } \\
\text { a period of } 10 \text { years) }\end{array}$ & $1.95(3.98$ & $\begin{array}{l}3.87 \\
(5.38)\end{array}$ & $1.43(3.45)$ & $\begin{array}{l}1.91 \\
(3.86)\end{array}$ & $\begin{array}{l}1.58 \\
(3.70)\end{array}$ & $0.01 * *$ \\
\hline $\begin{array}{l}\text { Number of times nearest earth/sand dams } \\
\text { dried up (over a period of } 10 \text { years) }\end{array}$ & $3.03(4.35)$ & $\begin{array}{l}4.82 \\
(4.50)\end{array}$ & $1.73(3.41)$ & $\begin{array}{l}3.55 \\
(4.65)\end{array}$ & $\begin{array}{l}2.53 \\
(4.28)\end{array}$ & $0.00 * *$ \\
\hline $\begin{array}{l}\text { Number of times water pans dried up (over a } \\
\text { period of } 10 \text { years) }\end{array}$ & $2.62(4.90)$ & $\begin{array}{l}4.67 \\
(8.79)\end{array}$ & 1.99 (3.94) & $\begin{array}{l}2.65 \\
(4.23)\end{array}$ & $2.16(395)$ & $0.03 * *$ \\
\hline $\begin{array}{l}\text { Number of times other sources dried up (over } \\
\text { a period of } 10 \text { years) }\end{array}$ & $1.21(3.40)$ & $\begin{array}{l}4.00 \\
(6.10)\end{array}$ & $1.02(2.86)$ & $\begin{array}{l}0.87 \\
(2.76)\end{array}$ & $\begin{array}{l}0.26 \\
(1.62)\end{array}$ & $0.00 * *$ \\
\hline
\end{tabular}

Note: Figures in parenthesis indicate standard deviation

**indicate significant at $5 \%$ level of significance

\subsection{2: Potential impact indices in the study area}

Potential index was calculated as the sum of exposure index and sensitivity index. The results indicated that exposure to climate variability and extreme was highest in Yuku (exposure index $=1.000$ ) and least in Kaveta sub-location (exposure index=0.057; Table 4). The high exposure index in Yuku sub-location could be attributed to high incidences of climate related natural disasters such as floods, droughts, strong winds, forest fires and community inter-border conflicts. On the contrary, low exposure index in Kaveta could be explained by minimal occurrences of the climate related disasters over a period of ten years. The mean value for total disasters was higher in Kauwi compared to Kasaini sub-location as indicated in Table 4.5 thereby resulting to higher exposure in Kauwi sub-location.

Similarly, Yuku sub-location had the highest sensitivity index (0.853) while Kaveta sub-location had the lowest sensitivity index 0.106 (Table 4). High sensitivity in Yuku sub-location could be explained by highmean values for sensitivity indicators particularly human and livestock fatalities as well as houses, productive land and roads damaged by extreme climatic events. The mean value for non-natural resource-based income was lowest in Yuku significantly contributing to the high sensitivity index. Conversely, Low sensitivity in Kaveta sub-location could be attributed to lesser incidences of the sensitivity indicators coupled with highest mean values for non-natural resourcebased income which as hypothesized reduced sensitivity of the area to climate variability and extremes. Potential impact index was highest in Yuku, followed by Kauwi, Kasaini and Kaveta sub-location. Despite Kauwi performing better in sensitivity index than Kasaini, its exposure index was comparatively high resulting to higher potential impact index in the sub-location compared to Kasaini (Table 4). 
Table 4: Potential impact indices in the study area

\begin{tabular}{|c|c|c|c|c|c|}
\hline \multicolumn{6}{|c|}{ Sub-locations } \\
\hline & Indicators & Yuku & Kaveta & Kauwi & Kasaini \\
\hline \multirow{9}{*}{$\begin{array}{l}\text { Indicator } \\
\text { variables } \\
\text { for } \\
\text { exposure }\end{array}$} & Floods & 1.000 & 0.000 & 0.660 & 0.310 \\
\hline & Droughts & 1.000 & 0.000 & 0.720 & 0.110 \\
\hline & Strong winds & 1.000 & 0.090 & 0.400 & 0.000 \\
\hline & Wild/forest fires & 1.000 & 0.120 & 0.030 & 0.000 \\
\hline & Livestock diseases & 1.000 & 0.000 & 0.510 & 0.200 \\
\hline & $\begin{array}{l}\text { Community inter-border } \\
\text { conflicts }\end{array}$ & 1.000 & 0.190 & 0.010 & 0.000 \\
\hline & Human-wildlife conflict & 1.000 & 0.000 & 0.010 & 0.050 \\
\hline & Sub-total scores & 7.00 & 0.40 & 2.34 & 0.67 \\
\hline & Exposure Indices & 1.000 & 0.057 & 0.334 & 0.096 \\
\hline \multirow{16}{*}{$\begin{array}{l}\text { Indicator } \\
\text { variables } \\
\text { for } \\
\text { sensitivity }\end{array}$} & Human fatalities & 1.000 & 0.003 & 0.001 & 0.000 \\
\hline & Livestock fatalities & 1.000 & 0.000 & 0.016 & 0.010 \\
\hline & Houses damaged & 1.000 & 0.060 & 0.098 & 0.000 \\
\hline & Roads damaged & 1.000 & 0.035 & 0.000 & 0.000 \\
\hline & Productive land damaged & 1.000 & 0.021 & 0.141 & 0.000 \\
\hline & Natural resource income & 1.000 & 0.000 & 0.324 & 0.691 \\
\hline & Non-natural resource income & 0.000 & 1.00 & 0.199 & 0.779 \\
\hline & Rivers dried up & 0.779 & 0.000 & 1.000 & 0.697 \\
\hline & Boreholes dried up & 1.000 & 0.267 & 0.017 & 0.000 \\
\hline & Shallow wells dried up & 1.000 & 0.000 & 0.542 & 0.600 \\
\hline & Springs dried up & 1.000 & 0.000 & 0.197 & 0.061 \\
\hline & Earth/sand dams dried up & 1.000 & 0.000 & 0.589 & 0.259 \\
\hline & Subtotal scores & 10.779 & 1.386 & 2.88 & 3.15 \\
\hline & Sensitivity indices & 0.853 & 0.106 & 0.240 & 0.315 \\
\hline & Potential impact indices & 1.853 & 0.163 & 0.574 & 0.411 \\
\hline & Rank & 1 & 4 & 2 & 3 \\
\hline
\end{tabular}

3.3.1 Adaptive capacity of farmers to climate variability and extremes in the study area

Examination of results on mean values of adaptive capacity indicators revealed that Kaveta (semi-humid) had the highest asset possession while Kasaini (semi-arid) had the least asset possession among the study sub-locations. Based on results analyzed and presented in Table 5, Kaveta ranked best in three of the asset categories (human, financial and social assets) and second-best in physical assets, thereby scoring the highest in overall adaptive capacity index. Yuku ranked last in terms of human, financial and social assets; first in natural assets and faired averagely in physical assets thus, ranked second in terms of overall adaptive capacity index. On the other hand, Kauwi and Kasaini ranked third and fourth, respectively in terms of overall adaptive capacity index (Table 5).

Based on the results, the primary policy focus in the arid zones particularly Yuku, should be to increase their access to 
financial assets and improve human assets which could go a long way in improving other assets categories including social, physical and natural assets. Financial assets enable households to make investment in education and the savings can be used as capital for investments like buying good quality land or buying necessary inputs for cash crop cultivation such as cotton and the emerging "Ndengu (green gram) revolution". However, financial asset in Yuku was found to be very limited contrary to Kaveta due to the remoteness of the area, long distances to the market and fewer opportunities that generate cash income. Development of infrastructure that creates employment opportunities for cash income generation in the area is thus recommended. In addition, educational qualification among interviewed household heads was very low in the arid- Yuku sub-location and this could have negative consequences on their livelihoods. Consequently, low educational qualification could have hindered them from attaining the skills required to make more productive use of the available natural and physical resources. Policies should be geared towards improving the literacy rate of the community, and also towards providing trainings and vocational education for capacity building and skills development, so that they can diversify their livelihoods to more remunerative sources.

The current trend of results is in line with findings of Agnes et al. (2017) who established that smallholder farmers in Busia County, Kenya had low financial/economic adaptive capacity, moderate social and institutional knowledge and consequently, diminished informed farming related decision making capacity. The low financial and economic resource was explained by overreliance on climate sensitive rain- fed agriculture largely affected by erratic rainfall in Busia County. Therefore, the low financial and economic capacity among the smallholder farmers in Busia County reflected their limited ability to deal with and adapt to climate change effects. This affected smallholder farmers' ability to plan, prepare for, facilitate and implement adaptation measures. Similarly, Simotwo et al. (2018) reported that education levels, dependency ratio and farm sizes had positively significant association with farmers' adaptive capacity in Trans-Mara East, Kenya. The authors further indicated that there was a positive relationship between individual's marital status and diversity of livelihood streams and their adaptive capacity.

Table 5: Mean values for Indicators of Adaptive Capacity in the study area

\begin{tabular}{|c|c|c|c|c|c|c|c|}
\hline & Indicators & $\begin{array}{l}\text { Aggregate } \\
(n=341)\end{array}$ & $\begin{array}{l}\text { Yuku } \\
(n=39)\end{array}$ & $\begin{array}{l}\text { Kaveta } \\
(\mathrm{n}=104)\end{array}$ & $\begin{array}{l}\text { Kauwi } \\
(n=160)\end{array}$ & $\begin{array}{l}\text { Kasaini } \\
(\mathrm{n}=38)\end{array}$ & $\begin{array}{l}\text { P- } \\
\text { Value }\end{array}$ \\
\hline \multirow[t]{6}{*}{$\begin{array}{l}\text { Physical } \\
\text { asset }\end{array}$} & $\begin{array}{l}\text { Number of extension services } \\
\text { (last } 1 \text { year) }\end{array}$ & $\begin{array}{l}0.53 \\
(1.48)\end{array}$ & 0.59 (1.09) & $\begin{array}{l}0.95 \\
(2.35)\end{array}$ & $0.33(0.81)$ & $0.18(0.46)$ & $0.00^{* * * *}$ \\
\hline & $\begin{array}{l}\text { Number of sources of timely } \\
\text { weather information }\end{array}$ & $\begin{array}{l}1.23 \\
(1.00)\end{array}$ & $1.18(0.89)$ & $\begin{array}{l}1.47 \\
(1.23)\end{array}$ & $\begin{array}{l}1.09 \\
(085)\end{array}$ & $1.24(1.03)$ & $0.03 * *$ \\
\hline & $\begin{array}{l}\text { Distance to nearest motorable } \\
\operatorname{road}(\mathrm{KM})\end{array}$ & $\begin{array}{l}1.51 \\
(6.27)\end{array}$ & $\begin{array}{l}2.53 \\
(3.32)\end{array}$ & $2.28(10.90)$ & 0.98 (1.90) & $0.62(0.88)$ & 0.22 \\
\hline & $\begin{array}{l}\text { Distance in } \mathrm{Km} \text { to the nearest } \\
\text { market }\end{array}$ & $\begin{array}{l}2.79 \\
(3.24)\end{array}$ & $4.83(7.36)$ & $2.35(1.58)$ & $2.53(2.32)$ & $3.00(2.37)$ & $0.00^{* *}$ \\
\hline & $\begin{array}{l}\text { Distance to nearest Water } \\
\text { source }(\mathrm{KM})\end{array}$ & $\begin{array}{l}1.49 \\
(2.41)\end{array}$ & $4.23(5.53)$ & $1.21(1.20)$ & $1.10(1.30)$ & $1.04(1.22)$ & $0.00^{* *}$ \\
\hline & $\begin{array}{l}\text { Distance to nearest health } \\
\text { facility }(\mathrm{KM})\end{array}$ & $\begin{array}{l}3.51 \\
(3.75)\end{array}$ & $8.31(7.44)$ & $2.62(2.01)$ & $2.92(2.59)$ & $3.50(2.08)$ & $0.00^{* * *}$ \\
\hline \multirow[t]{2}{*}{$\begin{array}{l}\text { Human } \\
\text { asset }\end{array}$} & $\begin{array}{l}\text { Highest number of formal } \\
\text { schooling years }\end{array}$ & $12.43(4.42)$ & $\begin{array}{l}10.85 \\
(3.98)\end{array}$ & $13.07(4.74)$ & $\begin{array}{l}12.40 \\
(4.18)\end{array}$ & $\begin{array}{l}12.42 \\
(4.68)\end{array}$ & $0.02 * *$ \\
\hline & $\begin{array}{l}\text { Number of persons in the } \\
\text { family with salaried jobs }\end{array}$ & $\begin{array}{l}0.64 \\
(1.07)\end{array}$ & $0.44(0.85)$ & $0.91(1.31)$ & $0.50(0.85)$ & $0.66(1.26)$ & $0.01 * *$ \\
\hline
\end{tabular}




\begin{tabular}{|c|c|c|c|c|c|c|c|}
\hline & & 0.57 & $0.44(0.85)$ & $0.83(1.19)$ & $0.45(0.85)$ & $0.50(0.76)$ & $0.01 * *$ \\
\hline & $\begin{array}{l}\text { Trainings/vocational courses } \\
\text { in the family }\end{array}$ & $(0.97)$ & & & & & \\
\hline & $\begin{array}{l}\text { Farming experience by } \\
\text { household head }\end{array}$ & $\begin{array}{l}25.63 \\
(16.55)\end{array}$ & $\begin{array}{l}19.28 \\
(12.20)\end{array}$ & $26.59(15.35)$ & $\begin{array}{l}26.42 \\
(17.64)\end{array}$ & $\begin{array}{l}26.16 \\
(17.99)\end{array}$ & $0.04 * *$ \\
\hline Natural & Size of productive land (acres) & 4.35 & 8.72 & 2.34 & 4.72 & $3.80(3.67)$ & $0.00 * *$ \\
\hline asset & & $(5.71)$ & $(10.83)$ & $(2.77)$ & $(5.09)$ & & \\
\hline & Size of unproductive land & 1.20 & 6.00 & 0.62 & 0.56 & $0.57(1.21)$ & $0.00^{* *}$ \\
\hline & (acres) & $(4.30)$ & $(10.70)$ & $(1.78)$ & $(1.82)$ & & \\
\hline & Small livestock & 5.74 & 8.56 & 2.50 & 7.13 & $5.84(6.75)$ & $0.00^{* *}$ \\
\hline & & $(8.81)$ & (11.17) & $(3.12)$ & $(10.40)$ & & \\
\hline & Large livestock & 2.42 & 6.15 & 1.26 & 2.32 & $2.13(2.22)$ & $0.00^{* *}$ \\
\hline & & $(3.50)$ & $(6.85)$ & $(1.74)$ & $(2.74)$ & & \\
\hline Financial & Gross household income & 20513.80 & $13095.50(1$ & 26453.40 & 19583.50 & 15944.70 & 0.51 \\
\hline asset & /month & $(53271.60)$ & 9727.90) & $(68048.00)$ & $(52978.30)$ & $(24359.50)$ & \\
\hline & Household savings /month & 2161.60 & $843.80(251$ & 2933.00 & $2121.40(64$ & $1592.10(65$ & 0.45 \\
\hline & & $(7275.60)$ & $6.00)$ & $(9593.90)$ & $40.50)$ & $32.50)$ & \\
\hline & Total annual earnings from & 165687.3 & 127039.30( & 189789.10 & 149416.10( & 208534.40( & 0.72 \\
\hline & livelihood strategies & $(415236.4)$ & 115022.8) & $(477960.40)$ & $344170.2)$ & $648955.60)$ & \\
\hline Social & CBO memberships (number) & $8.06(38.62)$ & 2.57 & $17.67(64.50)$ & 2.79 & 3.82 & 0.21 \\
\hline asset & & & $(4.00)$ & & $(4.41)$ & $(6.89)$ & \\
\hline & Cooperative & 7.82 & 1.00 & 4.16 & $1.70(5240$ & 3.71 & 0.69 \\
\hline & memberships (number) & $(3819.31)$ & $(0.00)$ & $(14.15)$ & 59) & $(364.80)$ & \\
\hline & $\begin{array}{l}\text { Credit facilities accessed /last } \\
5 \text { years }\end{array}$ & $\begin{array}{l}1414.86 \\
(9482.25)\end{array}$ & $\begin{array}{l}1282.26 \\
(6561.2)\end{array}$ & $\begin{array}{l}1951.94 \\
(8895.1)\end{array}$ & $\begin{array}{l}1896.63(11 \\
175.1)\end{array}$ & $\begin{array}{l}1789.84 \\
(4866.5)\end{array}$ & 0.84 \\
\hline
\end{tabular}

Note: Figures in parenthesis indicate standard deviation

**indicate significant at $5 \%$ level of significance

\subsubsection{Adaptive capacity indices in the study area}

Examination of the results established that Kaveta had the highest adaptive capacity index (0.693)followed by Yuku sub-location (0.366; Table 6). Despite Kaveta sub-location having highest indices for physical assets, human assets and majority of financial and social assets, the sub-location had lowest values for natural assets. Yuku sub-location ranked second as regards adaptive capacity index owing to the high values for natural assets such as size of land, size of productive land and number of small and large bullocks owned. However, Yuku had the lowest human, physical, financial and social assets. 
Table 6: Adaptive capacity indices in the study area

\begin{tabular}{|c|c|c|c|c|c|}
\hline $\begin{array}{l}\text { Indicator variables for adaptive } \\
\text { capacity }\end{array}$ & Sub-locations & Yuku & Kaveta & Kauwi & Kasaini \\
\hline \multirow[t]{3}{*}{ Physical assets } & Gadgets owned & 0.026 & 1.000 & 0.322 & 0.000 \\
\hline & $\begin{array}{l}\text { Reliable weather } \\
\text { information sources }\end{array}$ & 0.237 & 1.000 & 0.000 & 0.395 \\
\hline & Nearest market & 1.000 & 0.000 & 0.073 & 0.262 \\
\hline \multirow[t]{4}{*}{ Human assets } & Schooling years & 0.000 & 1.000 & 0.698 & 0.707 \\
\hline & Family salaried jobs & 0.000 & 1.000 & 0.128 & 0.468 \\
\hline & $\begin{array}{l}\text { Trainings/vocational in } \\
\text { family }\end{array}$ & 0.000 & 1.000 & 0.026 & 0.154 \\
\hline & Farming experience & 0.000 & 1.000 & 0.977 & 0.941 \\
\hline \multicolumn{6}{|l|}{ Natural assets } \\
\hline & Productive land & 1.000 & 0.000 & 0.373 & 0.229 \\
\hline & Unproductive land & 1.000 & 0.011 & 0.000 & 0.002 \\
\hline & Small livestock & 1.000 & 0.000 & 0.764 & 0.551 \\
\hline & Large livestock & 1.000 & 0.000 & 0.217 & 0.178 \\
\hline \multirow[t]{3}{*}{ Financial assets } & Gross income & 0.000 & 1.000 & 0.486 & 0.213 \\
\hline & Household savings & 0.000 & 1.000 & 0.612 & 0.358 \\
\hline & $\begin{array}{l}\text { Earnings from livelihood } \\
\text { strategies }\end{array}$ & 0.000 & 0.770 & 0.275 & 1.000 \\
\hline \multirow[t]{3}{*}{ Social assets } & Access to extension services & 0.532 & 1.000 & 0.195 & 0.000 \\
\hline & CBO memberships & 0.000 & 1.000 & 0.015 & 0.088 \\
\hline & Access to credit facilities & 0.424 & 1.000 & 0.9552 & 0.000 \\
\hline Sum of scores & & 6.219 & 11.781 & 6.112 & 5.546 \\
\hline Adaptive capacity index & & 0.366 & 0.693 & 0.360 & 0.326 \\
\hline Rank & & 2 & 1 & 3 & 4 \\
\hline
\end{tabular}

\subsection{Overall vulnerability indices in the study area}

The results in Table 7 indicated that among the selected study sites, Yuku sub-location ranked the most vulnerable to climate variability and extremes (1.487) while Kaveta sublocation was the least (-0.530). Despite Kauwi having relatively higher adaptive capacity and lower sensitivity index compared to Kasaini, it still ranks the second most vulnerable sub-location owing to its high exposure index. In spite of having lower adaptive capacity than Kauwi suslocation, Kasaini sub-location ranked better in overall vulnerability as it faced less exposure. The two least vulnerable sub-locations have the least exposure to climate variability and extremes. However, higher sensitivity coupled with low adaptive capacity results to higher vulnerability in Kasaini compared to Kaveta.

The results are in consonance with findings of Luniet al. (2012) who established that the most vulnerable households are always the ones with the lowest adaptive capacity, highest exposure and sensitivity indices irrespective of the locality. Thus, improving the adaptive capacity of these vulnerable households will also invariably reduce their sensitivity and finally decreases their overall vulnerability. Agro-ecological zones' comparison of vulnerability showed that despite having higher adaptive capacity, such capacity 
may not be fully realized in the face of higher exposure and sensitivity (Ndunguet al.,2015).

Table 7: Vulnerability Indices in the study area

\begin{tabular}{|llllllll|}
\hline Sub- & Exposure & $\begin{array}{l}\text { Sensitivity } \\
\text { locations }\end{array}$ & $\begin{array}{l}\text { Potential impact } \\
\text { index }\end{array}$ & $\begin{array}{l}\text { Adaptive } \\
\text { index }\end{array}$ & capacity & $\begin{array}{l}\text { Vulnerabilit } \\
\text { index }\end{array}$ & Rank \\
Yuku & 1.00 & 0.853 & 1.853 & 0.366 & 1.487 & 1 \\
Kaveta & 0.057 & 0.106 & 0.163 & 0.693 & -0.530 & 4 \\
Kauwi & 0.334 & 0.240 & 0.574 & 0.360 & 0.214 & 2 \\
Kasaini & 0.096 & 0.315 & 0.411 & 0.326 & 0.085 & 3 \\
\hline
\end{tabular}

\section{CONCLUSION AND POLICY AND RECOMMENDATIONS}

The present study established that farmers in arid agroecological zone were the most vulnerable to climate variability and extremes while those in semi-humid zone were the least vulnerable. In addition, the study revealed that biophysical elements determining exposure to climate variability and extremes like temperature, rainfall and climate related natural disasters were beyond the immediate influence of the policy makers. Therefore, amongst the three components of vulnerability, adaptive capacity was found to have direct policy implications. Further, improving the adaptive capacity also had indirect implications on improving the sensitivity of the farmers. For this reason, enhancing adaptive capacity through creating opportunities for off-farm income, improving infrastructure for community development, provision of post-disaster relief measures and establishment of early warning systems would go a long way in reducing vulnerability to climate variability and extremes in Kitui County.

\section{ACKNOWLEDGEMENT}

The authors are grateful to Climate Smart Agriculture Project, South Eastern Kenya University for sponsoring the study.

\section{REFERENCES}

[1] Agnes, M. S., Alice, K. and Richard, M.B. (2017) Adaptive Capacity to Climate Change among Smallholder Farmers' in Busia County, Kenya. OSR Journal of Agriculture and Veterinary Science (IOSR-JAVS) Volume 10, Issue 11 Ver. I (November 2017), e-ISSN: 2319-2380, ISSN: 2319-2372.

[2] Christensen, J. H., Hewitson, B., Busuioc, A., Chen, A., Gao, X., Held, I., Whetton, P. (2007). Regional Climate Projections Climate Change 2007: The Physical Science Basis. Contribution of Working Group I to the Fourth
Assessment Report of the Intergovernmental Panel on Climate Change. Cambridge: IPCC.

[3] Collier, P., Conway, G. and Dewey, J. (2008). Climate Change and Africa. Oxford Rev EconPol, 24(2): 337- 350.

[4] Davis, B, Winters, P. and Lee, K. (2007). RuralIncome Generating Activities: A Cross CountryComparison. ESA Working Paper 68. FAO, Rome.

[5] DFID (1999): Sustainable Livelihoods Guidance Sheets. London, UK: Department for International Development

[6] Ellis, F. (2000): Rural Livelihoods and Diversity in Developing Countries. Oxford University Press, New York. 45-46.

[7] FAO (Food and Agriculture Organization of the United Nations). (2016) Family Farmers: Feeding the World, Caring for the Earth. FAO, Rome, Italy.

[8] Government of Kenya (GoK), (2009) Kenya National Bureau of statistics; The 2009 Kenya Population and Housing Census.

[9] Hulme, M., Doherty, R.M., Ngara, T., New, M.G. and Lister, D. 2001. African climate change: 1900-2100. Climate Research 17(2): 145-168.

[10] Khisa, G.V., Oteng'i, S.B., and Mikalitsa S.M. (2014). Effect of Climate Change on Small Scale Agricultural Production and Food Security in Kitui District, Kenya.

[11] Luni, P. Maharjan, K., Joshi, N. (2012) Perceptions and realities of climate change among the Chepong Communities in rural mid-hills of Nepal. J. Contemp. India Stud. Space Soc. 2, 3550 .

[12] LVBC (2011). Vulnerability assessment to climate change in Lake Victoria Basin.

[13] Marshall, N. A., Marshall, P. A., Tamelander, J., Obura, D., Malleret-King, D., \& Cinner, J. E. (2009). A Framework for Social Adaptation to Climate Change: Sustaining Tropical Coastal Communities and Industries. Switzerland: IUCN.

[14] Ndungu C.K., Bhardwaj S.K., Sharma D.P., Sharma R., Gupta R.K. and Sharma B. (2015) Vulnerability Assessment of Rural Communities to Environmental Changes in MidHills ofHimachal Pradesh in India. Netherlands Institute of Meteorology.

[15] Republic of Kenya (2005) Economic Survey 2005. Government Printer, Nairobi. 
[16] Simotwo, H. K., Stella M. M. and Boniface N. W (2018) Climate Change Adaptive Capacity andSmallholder Farming in Trans-Mara East sub-County, Kenya. Geoenvironmental Disasters (2018) 5:5.

[17] Spear, Dian, Baudoin, Marie-Ange, Hegga, Salma, Zaroug, Modathir, Okeyo, Alicia E. Haimbili, E. (2015). Vulnerability and Adaptation to Climate Change in the Semi-Arid Regions of Southern Africa.

[18] UNDP (2006) Human development report, United Nations Development Program. Available at: http://hdr.undp.org/hdr2006/statistics/

[19] Van oldenborgh, B. B., Hellquist, G., Rodjer, S., Gunnarsson, R., Björkelund, C. andWahlqvist, M. (2008). Medical students' and facilitators' experiences of an Early Professional Contact course: Active and motivated students, strained facilitators. BMC medical education, 8(1), 56.

[20] Zoellick B (2009). A Climate Smart Future. The Nation Newspapers. Vintage Press Limited, Lagos, Nigeria. 18 